\title{
Comportamento ingestivo de potros da raça Crioula com 5 meses de idade na fase de cria
}

João Danilo Biffi Pereira, Marcele Sousa Vilanova, Catia Dal Bello Giacomet, Caroline Braga Andelieri, Willian Perin

Universidade de Caxias do Sul(UCS), Caxias do Sul, RS, Brasil

*Autor correspondente

e-mail: joao.danilo@hotmail.com

\section{Resumo}

O bem-estar animal é uma ciência em desenvolvimento, que busca as relações mais respeitosas entre os humanos e os animais. Uma das bases fundamentais para a manutenção desse equilíbrio é o entendimento das variáveis comportamentais que influenciam os animais em pastejo, pois desde a domesticação dos equinos, diversas são as situações de manejo alimentar inadequadas resultantes do restrito conhecimento desses animais a campo. 0 objetivo do trabalho foi avaliar o comportamento ingestivo de potros com cinco meses de idade, acompanhados de suas mães, em pastagem de campo nativo melhorado, durante os turnos da manhã, meio-dia e tarde. 0 experimento foi realizado na Cabanha Tamboré, localizada no município de São Francisco de Paula/RS. Foram selecionadas oito éguas com idade média de 9 anos, prenhas (entre 120 a 180 dias gestação) com seus potros ao pé. Os animais foram alocados em um potreiro de 8 ha, composto por pastagem nativa, melhorada com trevo branco, trevo vermelho e cornichão. A coleta dos dados foi realizada nos dias 24, 25 e 26 de março de 2017, durante o período das $8 \mathrm{~h}$ às $18 \mathrm{~h}$. Foram anotadas as frequências de realização dos comportamentos de pastejo, deslocamento, ingestão de água e de sal mineral, ócio, dormindo, mastigando, defecando/urinando, realizando exercício/brincando, se coçando, potro mamando, interação potro com égua e interação potro com potro. 0 método de avaliação utilizado foi do etograma, técnica de amostragem do animal focal, com intervalos de 10/10 minutos entre as observações (Del-Claro, 2004). 0 tempo despendido com os comportamentos foi transformado em percentual (tendo como base 600 minutos totais de avaliação), os dados foram submetidos à análise da variância e as médias comparadas pelo teste de Tukey (5\%). A frequência percentual total despendida com os comportamentos foi de 50,8 em pastejo, 16,4 em ócio, 13,5 dormindo, 6,7 deslocando-se, 2,3 em interação potro com potro, 2,2 com ingestão de sal mineral, 1,9 potro mamando, 1,6 se coçando, 1,4 mastigando, 1,2 defecando/urinando, 1,0 interação potro com égua, 0,6 realizando exercício/brincando e 0,4 bebendo água. Os comportamentos que 
foram influenciados pelo turno de avaliação foram: Pastejo (Manhã: 14,0b; Meio-dia: 16,0b; Tarde: 20,7a), ingerindo sal mineral (Manhã: 0,5b; Meio-dia: 1,4a; Tarde: 0,4b) e dormindo (Manhã: 7,6a;, Meio-dia: 4,2b; Tarde: $1,7 \mathrm{c}$ ). Os potros com cinco meses de idade já apresentam como comportamento prioritário a ingestão de alimento sólido (pasto), uma vez que já estão preparados para o desmame que acontecerá aos seis meses de idade. A atividade de pastejo é substituída no turno da manhã pela de dormir e volta a ser prioridade no turno da tarde, onde os potros elevam a ingestão de alimento e dormem menos. Foi constatado que antes de iniciar o sono, os potros se acalmam e permanecem um período em ócio, conforme observado nos resultados. Segundo Santos (2014), os animais destinaram maior parte do tempo ao ato de pastar, sendo que as diferentes categorias animais apresentaram uma média diurna em pastejo de 8 horas e 35 minutos (37,5\%). Já segundo Meyer (1995), os equinos permanecem de 12 a 18h (50 a 75\%) em pastejo, consumindo em porções frequentes de pequenos bocados, durante períodos noturnos e diurnos. 0 fato de neste trabalho a frequência ter sido de $50,77 \%$ de pastejo pode estar relacionada ao fato de as avaliações finalizarem as $18 \mathrm{~h}$, não ocorrendo no turno da noite. 0 conhecimento das atividades realizadas pelos potros aos 5 meses de idade pode ser um indicativo para decisão mais precisa do período de desmame, uma vez que indica a total capacidade do animal em realizar a colheita do alimento e manutenção da nutrição adequada, diminuindo significativamente a dependência do leite materno.

Palavras-chave: Bem-estar animal. Pastejo. Campo nativo. 